\title{
Geographical Elements In The Puranas
}

Damodar Jnawali, PhD

Professor, Department of Geography Education

T.U, Nepal

\begin{abstract}
The central focus of this paper is on the geographical elements like mountains, rivers and places mentioned in the Puranas. Among them, Bhagavatamahapurana has mainly been consulted for this purpose. The source indicates that the names of the mountains and rivers are similar even today as they were in the ancient period. The paper describes the fact that no one can find out the exact knowledge about the universe. The universe is within the subject of the Vedic Cosmology. This cosmology has also been narrated in the Puranas. The universe is endless and has no limited boundary. All the living beings that appear today were created by the God and at last merge into the God. This tradition continues. The atheists do not believe the God. However, they accept the nature as all in all.
\end{abstract}

Key Words: Vedas, Puranas, satwiki, rajasi, tamasi, cosmology, geographical elements, dvipas, rivers, mountains.

\section{INTRODUCTION}

'Veda' means knowledge. Rigveda is the oldest work in the world. It is the major source of all the religions. So it is said वेदोडखिलो धर्ममूलम्‘ Vedokhilodharmamoolam'. Vedas are the root of all the religions. Vedas were created by the Lord Vishnu at the very beginning. However, there is no composer of Veda. It was transferred from generation to generation. There were many sages who observed the Vedas. In this context, the Vedas are Apaurusheya. In reality, the Vedas were created by the Lord Vishnu and given to Brahma, the creator of the universe. It was created to enlighten the human beings. Tiwari (nd) has stated that environmental science was originated from the Vedas. Vedas have given a message for protecting and preserving the environment. Jnawali (2010) has recorded fire, light, water, precipitation and air as the five geographical elements described in the Vedas.

The root of Adhyatma Vidya or spiritual science based on Hindu Philosophy is Veda. This Adhyatma Vidya has three parts. They are Jnanakanda, Karmakanda and Upasana or Bhaktikanda. Atharvaveda is Jnanakanda, Yajurveda is Karmakanda and Samaveda is related to Upasana or Bhaktikanda (Jnawali, 2005). Rigveda is the biggest work among the Vedas. It is the oldest work in the world. It is Vijnana Kanda. It is the root of all the four Vedas. It includes other components of Jnana, Karma and Upasana (Pandeya, 2002). Vedas are very difficult to understand. The subject-matter stated in the Vedas has been made simple in the Puranas.

Vedas are also known as Shrutis. They are the root of all the schools of Hindu philosophy. Since Vedas are the most difficult, Vedavysa composed Puranas in order to simplify their subject matter and make it more understandable among the people.

For remembering the name of the Puranas, following mantra or sloka is available in the Vamanpurana and Devibhagavat:

$$
\begin{aligned}
& \text { मद्वयं भद्वयं चैव ब्रत्रयं वचतुष्टकं। } \\
& \text { अनापलिंगकूस्कानि पुराणानि पृथक् पृथक् ॥ }
\end{aligned}
$$

Ma dvayam bha dvayam chaiva bra trayam va chatustakam

Anapalingakooskani puranani prithak prithak

In this sutra, ma indicates two Puranas. They are Matsya and Markandeya. Bha represents two Puranas. They are identified as Bhagavat and Bhavishya. The letter Bra is used for three Puranas Brahma, Brahmanda and Brahmavaivarta. $V a$ is used for four which are known as Vaman, Vishnu, Vayu and Varaha. The terms Vayu and Shiva are synonymously used. Anapalingakuska represents seven Puranas. They are Agni, Narada, Padma, Linga, Garuda, Kurma and Skanda.

Present paper is an attempt to introduce Vedas and Puranas in brief. It describes the types of the Vedas and Puranas. The central focus of this paper is on the geographical elements like mountains, 
rivers and places mentioned in the Puranas. The Bhagavatmahapurana has mainly been consulted for this purpose.

\section{METHODS AND MATERIALS}

The paper is based on the secondary information available from the documents published. An attempt was made to review selected references and papers. For this purpose, the Bhagavatamahapurana published by Geeta Press, Gorakhpur was consulted. Its fifth canto deals with creation of the universe. Similarly, the tenth canto was also reviewed for the explanation of the universe and living beings. Descriptive and analytical approaches have been adopted for arranging the materials.

\section{GEOGRAPHICAL ELEMENTS IN THE PURANAS}

\section{Introduction to Puranas}

Puranas are ancient texts, but it seems that they provide us new and updated knowledge. We can develop this type of feeling while reciting Bhagavatam. The author of this paper has recited all the texts of Bhagavatam eighteen times. Now he has a feeling that he has just entered into this Mahapurana for the first time. This is a dramatic surprise. It one starts to recite Bhagavatam, he/ she will develop this feeling. The Puranas represent the status of culture and civilization of the human beings. In spite of this, they are the sources of history and geography. The drama of history is played at the stage of geography. The activities of kings and warriors are the components of history. Each of the puranas deals with some components of geography. Padma Purana is Satwika Purana. It contains 55000 Shlokas. One of its sections is known as Srishti khanda. It deals with the creation of the universe.

The eighteen Puranas are classified as follows (Jnawali, 2005):

Satwika - Padma, Vishnu, Varaha, Bhagavat, Narada and Garuda. These are closely related to Lord Vishnu, the creator of the creator.

Rajasi - Brahmanda, Brahma, Brahmavaivarda, Markandeya, Bhavisya and Vaman are categories as Rajasi Puranas. They are related to Lord Brahma, the creator of the universe.

Tamasi - Shiva, Agni, Linga, Skanda, Kurma and Matsya are identified as Tamasi Puranas. Lord Shiva is God in these puranas.

There are some characteristics of Puranas. Generally they are five and described as (Dikshit, 2004):
सर्गश्च प्रतिसर्गश्च वंशो मन्वनतराणि च । वंश्यानुचरितं चेति पुराणं पन्चलक्षणम् ॥

'Sargascha pratisargascha vamso manwantarani cha Vamshanucharitam cheti Puranam panchalakshanam.'

Sarga, pratisarga, vamsha, manwantara, and vamshanucharita are the five characteristics of the Puranas. These are common properties. In the Bhagavatam, the ten characteristics are mentioned. They are explained as Sarga, Visarga, Sthana, Poshana, Uti, Manwantara, Ishanukatha, Nirodha, Mukti and Ashraya (Shrimadbhagavat /2/10/1).

Little knowledge is a dangerous thing. The persons who have not studied Sanskrit deeply or who do not have attachment with Lord Krishna will not be able to develop positive thinking about Bhagavatam. Without the blessings of Lord Krishna and Radharani, no creature is able to devote himself/ herself to this great work of Vedantadarshanam.

\section{Geographical Elements in the Puranas}

There are a number of geographic elements in the Puranas. These elements are available in various Puranas like Padma, Vishnu, Bhagavata, Brahmavaivarta, Brahma and others. The term 'Bharatvarsha' is well explained in the Puranas. It is a geographical term whereas the narration of Yaduvansha or Kuruvansha is related to the history. Based on the Puranas, the earth is divided into seven parts which are known as 'Dvipas'. This word indicates the continents. The seven parts of the earth in the Puranas are identified as Jambu dvipa, Plaksha dvipa, Salmali dvipa, Kusa dvipa, Krauncha dvipa, Saka dvipa and Puskara dvipa. This is the core concept of geography stated in the Srimadbhagavatamahapurana (Panchamaskandha).

The Srimadbhagavatamahapurana is at the top among all the Puranas. It is used in the Saptaha Jnanamahayajna. These days, it has been widely utilized for social and educational services like schools, hospitals and ashrams for elderly people. The devotion and activities of Late Pandit Narayan Pokhrel are its example. Now Pt. Deenabandhu is devoted to this activity. The works and activities performed by Lord Krishna in the Bhagavatam works as the source of inspiration for those who cannot devote their time to performing duties and responsibilities. The indecision of Arjuna in the Bhagavatgeeta is a great example for the whole humanity.

There is one section in the Bhagavatam mainly related to the creation of the world. All the seven dvipas are beautifully mentioned in the Panchamaskandha (Canto 5) of this Purana. Many rivers, mountains and sarovars (lakes) are mentioned in the Bhagavatam. It has been stated that the great 
rishi Jadabharata performed meditation at the bank of the Krishnagandaki. Rurukshetra as one of the most famous pilgrimages is located at the bank of the Kaligandaki River.

The story of Kardama Devahuti Vihar is closely linked to Vindusarovara tirtham.

During the process of explaining Vedastuti in the Bhagavatam, it is stated:

एकदा नारदो लोकान् पर्यटन् भगवत्प्रियः ।

सनातनमृषिं द्रष्टुं ययौ नारायणाश्रमम् ॥

‘Ekada narado lokan paryatan bhagavatpriyah

Sanatanmrishim drashtum yayau narayanashramam.

Shrimadbhagavatam 10/87/5/

Once when Narada, the beloved of the Lord was traveling in different planets, he desired to personally meet the ascetic Narayana in Badarikasrama and offer him his respects. Here, Kalapgrama near Badrikashrama has been mentioned as a holy place where the people used to gather for discussing about the subject of the Vedas.

Bharatavarsha is again mentioned in the fifth canto. Bharatavarsha was named after the reign of King Bharata. Bharata was a great king. He was the son of Dushyanta and Shakuntala. Another Bharat is well identified as Jadabharat, a great scholar and enlightened one. Jadabharat was brought to Bhadrakali temple for offering sacrifice to the Goddess. The Goddess appeared in real feature/vigraha and saved Jadabharata. Later on, Jadabharat gave enlightenement to the King Rahugana who was approaching Kapilaashrama. There is a long dialogue between the king and Mahatma Jadabharata. A beautiful example of the words expressed by Rahugana is presented here. King Rahugana was approaching towards the Kapilashram. He was ignorant and proud of his material world. He was surprised to see and listen to Mahatma Jadabharata. He became very polite and said:

कस्त्वं निगूढश्चरसि द्विजानां बिभर्षि सूत्रं कतमोऽवधूतः । कस्यासि कुत्रत्य इहापि कस्मात् क्षेमाय नश्चेदसि नेति शुक्ल : ॥

नाहं विशड्के सुरराजवज्रान्न त्र्यक्षशूलान्न यमस्य दण्डात् । नाग्यर्कसोमानिलवित्तपास्त्राच्छड्के भृशं ब्रह्मकुलावमानात् ॥

$$
\text { श्रीमद्भागवतमहापुराण ॥४।१०।१६-१७॥ }
$$

Kastvam nigood hascharasi dwijanam

bibharshi sootram katamovadhoota. kasyasi kutratya ihapi kasmat kshemaya naschedasi neti shukla. Naham vishanke sura-raja-vajran na tryakshashoolan na yamasya dandat nagnyarkasomanilavittapastrach chhanke bhrisham brahma-kulavamanat.
"Who are you? You are wearing a sacred thread. Are you Avadhoot who has challenged all the worldly things? Are you sage Kapila whom I want to meet? I am not afraid of thunderbolt of Indra or the trident of Lord Shiva. I am not afraid of the rod of Lord Yama, nor of the weapons of fire-god, the sun, moon, wind and Kubera. However, I am very afraid of the insult of persons of the Brahman community.

In a reply to Rahugana, Mahatma Jadabharata replied:

\section{अकोविद: कोविदवादवादान् वदस्यथो नातिविदां वरिष्ठ:। \\ न सूरयो हि व्यवहारमेनं तत्त्वावमर्शेन सहामनन्ति॥ श्रीमद्भागवतमहापुराण ॥स।११११॥ akovida. kovida-vada-vadan vadasyatho nati-vida. vari.ha. na soorayo hi vyavaharamenam tattvavamarshena sahamananti}

O king, you have no knowledge to distinguish right or wrong. However, you utter words like a scholar (Pandit). But you cannot be counted among great scholars. One who is tatwajnani does not discriminate persons as master and servant. Such a person cannot realize the reality.

After listening such words, Rahugana was surprised. He became very polite and said:

$$
\begin{aligned}
& \text { नमो नमः कारणविग्रहाय स्वरूपतुच्छीकृतविग्रहाय । } \\
& \text { नमोऽवधूत द्विजबन्धुलिड्गनिगूढनित्यानुभवाय तुभ्यम् ॥ } \\
& \text { श्रीमद्भागवतमहापुराण ॥४।१ श१॥ } \\
& \text { Namo nama karana-vigrahaya } \\
& \text { svaroopa-tuchchhikita-vigrahaya } \\
& \text { namovadhoota dvija-bandhu-linga- } \\
& \text { nigoodha-nityanubhavaya tubhyam }
\end{aligned}
$$

The king said, O Brahman, I greet you. You have taken this incarnation for the welfare of this world. You are in the form of Brahman Avdhoota. You are experiencing great pleasure in this form. I again and again greet you.

In a reply to Rahugana, Jadabharata further added:

$$
\text { ज्ञानं विशुद्ध परमार्थमेकमनन्तर त्वबहिर्ब्रह्म सत्यम् । }
$$

प्रत्यक् प्रशान्तं भगवच्छब्दसंज्ञ यद्वासुदेवं कवयो वदन्ति॥ श्रीमद्भागवतमहापुराण ॥ 19 श १९१॥

Jnanam visuddham paramarthameka-

manantaram tvabahirbrahma satyam

pratyak prashantam bhagavachchhabdasa jnam yad vasudevam kavayo vadanti

King Rahugana was very much pleased and said to Jadabharata: 
अहो नृजन्माखिलजन्मशोभनं किं जन्मभिस्त्वपरैरप्यमुष्मिन् ।

न यद्धृषीकेशयशः कृतात्मनां महात्मनां व: प्रचुर: समागमः ॥ नमो महद्भ्योऽस्तु नमः शिशुभ्यो नमो युवभ्यो नम आ वटुभ्य:। ये ब्राह्मणा गामवधूतलिड्गाश्चरन्ति तेभ्य: शिवमस्तु राज्ञाम् ॥

श्रीमद्भागवतमहापुराण ॥४।१३१२१,२३॥

aho $n$ ijanmakhila janma shobhanam ki janmabhistvaparair apyamu min na yad dh i shikeshayasha $\mathrm{k}$ itatmanam mahatmana va prachura samagama

namo mahadbhyostu nama shishubhyo namo yuvabhyo nama a vatubhya ye brahma a gamavadhoota-lingas charanti tebhya shivamastu rajnam

One of the statements related to creation is presented in the following extract of the fifth canto of the Bhagavatam:

$$
\begin{aligned}
& \text { 'ये वा उ ह तद्रथचरणनेमिकृतपरिखातास्ते सप्त सिन्धव } \\
& \text { आसन् यत एव कृता: सप्त भुवो द्वीपा: ॥ } \\
& \text { जम्बूप्लक्षशाल्मलिकुशक्रौन्चशाकपुष्करसंज्ञास्तेषां परिमाणं } \\
& \text { पूर्वस्मात्पूर्वस्मादुत्तर उत्तरो यथासंख्यं द्विगुणमानेन बहि: } \\
& \text { समन्तत उपक्लृप्ता: ॥' } \\
& \text { ॥ श्रीमद्भागवतमहापुराण ॥ห।१११,३२॥ }
\end{aligned}
$$

ye va $u$ ha tadratha chara anemik itaparikhataste sapta sindhava asan yata eva k ita sapta bhuvo dvipa . Jambu-plak ha-shalmali-kusha-kraunchashaka-pu kara-samjnaste am parima am purvasmat purvasmad uttara uttaro yatha-samkhyam dvi-gu a-manena bahi samantata upak ripta .

\section{भारतेऽप्यस्मिन् वर्षे सरिच्छैला: सन्ति बहवो मलयो मड्} गलप्रस्थो मैनाकस्त्रिकूट ॠषभ: कूटक: कोल्लुक: सह्यो दे वगिरिर्फ्टष्यमूक: श्रीशैलो वेड्कटो महेन्द्रो वारिधारो विन्ध्य: शुक्तिमानृक्षणिरि: पारियात्रो द्रोणश्चित्रकूटो गोवर्द्धनो रैवतक: ककुभो नीलो गोकामुख इन्द्रकील: कामगिरिरिति चान्ये च शतसहस्रश: शैलास्तेषां नितम्बप्रभवा नदा नद्यश्च

सन्त्यसंख्याता: ॥४॥9९ १६६॥

bharatepyasmin varshe sarichchaila santi bahavo malayo mangala-prastho mainakas triku a abha kutaka kollaka sahyo devagirirth yamuka shri-

shailo venkato mahendro varidharo vindhya suktimanri kshagiri pariyatro dron aschitrakooto govardhano raivataka kakubho nilo gokamukha indrakila kamagirir iti chanye cha shata-sahasrasa shailas tesham nitamba-prabhava nada nadyas cha santi asankhyatah.

In this Bharatavarsha, there are a number of mountains. Malaya, Mangalaprastha, Mainaka, Strikuta, Shrishaila, Venkata, Mahendra, Vindhya,
Chitrakuta and Gobardhana are the major mountains mentioned in this chapter. Malaya is also known as Malayachala. Some poets have composed poem stating wind blowing through Malaya. For example Malaya is stated :

\section{शरद ॠतु उदायो चन्द्रको कान्ति छायो मलयपवन चल्दा मेघमाला बिलायो।}

This stanza is in Malini Chhanda. It indicates that with the dawn of autumn, the light of moon was spread. The group of clouds disappeared with the movement of wind through Malayachala. This way, the poets are very much influenced by geographical objects like mountain and wind in composing new poems. This is known as romanticism. William Wordsworth of England and Laxmi Prasad Devkota of Nepal are great romantic poets.

एतासामपो भारत्यः प्रजा: नामभिरेव पुनन्तीनामात्मना चोपस्पृशन्ति ॥१७॥ चन्द्रवसा ताम्रपर्णी अवटोदा कृतमाला वैहायसी कावेरी वेणी पयस्विनी शर्करावर्ता तुड्गभद्रा कृष्णा वेण्या भीमरथी गोदावरी निर्विन्ध्या पयोष्णी तापी रेवा सुरसा नर्मदा चर्मण्वती सिन्धुरन्धः शोणशच नदौ महानदी वेदस्मृतिर्षषिकुल्या त्रिसामा कौशिकी मन्दाकिनी यमुना सरस्वती दृषदूती गोमती सरयू रोधस्वती सप्तवती सुषोमा शतद्रूशचन्द्रभागा मरुद्वृधा वितस्ता असिक्नी विश्वेति महानद्य: $195 \|$

॥श्रीमद्भागवतमहापुराण॥ १९९॥१७, १६॥

Etasamapo bharatya prajah namabhireva punantinamatmana chopasp isanti;

chandravasa tamraparnee avaoda $\mathrm{k}$ itamla vaihayasee kaveri veni payasvini sharkaravarta tungabhadra kansh venya bheemarathee godavaree nirvindhya payo ee tapee reva surasa narmada charma vatee sindhurandha sho ascha nadau mahanadee vedasm itir i hikulya trisama kaushiki

mandakinee yamunaā sarasvatee dihadvati gomati sarayoo rodhasvatee saptavatee su homa shatadruschandrabhaga marudv idha vitasta asiknaee vishveti maha-nadya .

The extract mentions the names of the rivers. River Kaveri and Krishna are located in south India. Krishna is also another name of Kaligandaki in Nepal which is world famous for Shaligram. Kaushiki is Koshi of Nepal; Yamuna flows through Delhi and Vrindavan; Saraswati is in Allahabad; Gomati is in Lucknow; Sarayu is in Ayodhya which is known as Karnali in Nepal. Thus, the rivers are well explained in the Bhagavatam. Rivers work as a source of inspiration for literary work. Kavivara Madhv Ghimire of Nepal states in Kaligandaki Poem as: 
कालीगंगा भनन कसरी कुद्दछयौ शालिग्राम ?

This line is a portion of the poem Kaligandaki composed by Madhav Ghimire. It is in Mandakranta prosody (Chhanda) that may be compared with a sweet sound of waterfall. The poem is very beautiful. Mukunda Sharan Upadhyaya has composed a poem known as Nari in the same prosody. These poets are very popular in the area of Nepali literature. Nari won gold medal in literary competition. Madhav Ghimire is widely known for Mandakranta prosody. His poem 'Navayuvaka' works as a source of inspiration for youth. He says, "He tanneri uthana prthivi tina bitta uchali." This way, literature is also influenced by geographical objects like mountain and wind.

In the literature, the Nayaka ie, major character is highly appreciated. Such appreciation is available in many parts of the Bhagavatam. The appreciation of Lord Vishnu is made by the Vedas. The 87th chapter of Dashamaskandha contains Vedastuti. Vedas are termed here as. It Shritis. Vedas appreciate the Lord as:

\section{श्रुतय: उचु: \\ जय जय जह्यजामजित दोषगृभीतगुणां \\ त्वमसि यदात्मना समवरूद्धसमस्तभगः । \\ अगजगदोकसामखिलशक्त्यवबोधक ते \\ क्वचिदजयाडsत्मना च चरतोऽनुचरेन्निगमः ॥ \\ ॥ श्रीमद्भागवतमहापुराण ॥१०६७१४॥}

The same Samhita has been stated by Bhakti

Vedanta Prabhupada as:

Jaya jaya jahyajamajita doagibhita gua

Tvamasi yadatmana samavaruddhasamastabhaga

Agajagadokasamakhilashaktyavabodhaka te

Kvachidajayatmana cha charatonucharennigama.

Shrutis or Vedas said, "O God, Lord Krishna, Jaya, Jaya, Jaya. You possess all the pleasures and happiness. You are almighty. You can transmit power into living and non-living beings. You have spread your Maya. As a result, these living beings cannot get rid of Avidya. So make us free from this Avidya or darkness. You show different activities. You create this universe and entertain it. The Vedas can describe you when you exist in your absolute state.

The shrutis address the Lord as Ajita. Ajita means one who cannot be defeated. Lord Krishna is Sarvavijayi. He is the kala of kala. They say that the Lord cannot be conquered by Maya. The other gods, even Brahma are defeated by their own faults. They sing the glory of Ajita Bhagavan. The Vedas sing: $\mathrm{O}$ Ajita, you are almighty; you possess all the pleasures and happiness; you can transmit power into living and non-living beings. You have spread your Maya. As a result, these living beings cannot get rid of Avidya or darkness. You show different types of activities. You create this universe and entertain it. We, the Vedas can describe you only when you exist in your absolute state. They highly appreciate the work of Lord Vishnu or Krishna.

The statement in the Bhagavatam related to the structure of the universe and living beings is:

$$
\begin{aligned}
& \text { न घटत उद्भव: प्रकृतिपूरुषयोरजयो- } \\
& \text { रुभययुजा भवन्त्यसुभृतो जलबुद्बुदवत् । } \\
& \text { त्वयि त इमे ततो विविधनामगुणे: परमे } \\
& \text { सरित इवार्णवे मधुनि लिल्युरशेषरसा: ॥ } \\
& \text { ॥ श्रीमद्भागवतमहापुराण ॥१०।इ७३१॥ }
\end{aligned}
$$

na ghatata udbhava prakitipooruayorajayo-

rubhayayuja bhavantyasubhito jalabudbudavat

tvayi ta ime tato vividhanamaguai parame sarita ivarave madhuni lilyurashesarasa

This Samhita of Bhagavatam states that the universe looks like a Ghatakash. When we observe it, it looks that the sky is just on the mountain. If we march ahead, it again appears same from another place. One cannot find out its starting and ending points. Who are the creators of such world? Who are the parents of Prakriti and Purusha? There is no correct answer. They are birthless (ajanma). Every human being accepts the role of nature. Nature is all in all. When Prakriti and Purusha come together, many living beings are created. Their shapes and structure are quite different. There are more than seven billion people in this world. No one is similar to another person. These creatures are like the drops in the ocean. At last, all these living beings merge into the nature as the streams into rivers, rivers into sea and sea into the great oceans and nectars of flower into honey. The small water bodies flow into the ocean. Then their existence is no more. The honey bee collects nectar from the flowers and prepares honey. When the honey is formed, there is no existence of nectar/juice of the flowers. The meaning is that the God or Nature is Almighty. He creates everything and at the end all the living beings like the drops of the Ocean merge into the God. This is a universal truth and may be applied to each of the religions and philosophies.

Many geographic elements are available in the Puranas (Dikshit, 2004). Some of them have been reviewed in this paper. Vedas are interpreted in the Suktas. The subject matter has been illustrated through Sutras. In the Puranas, the same subject matter has been explained in detail. 
In the Bhagavatam, it is stated:

\section{इतिहास पुराणन्च पञ्चमो वेद उच्यते ।}

Itihas-puranam cha panchamo veda uchyate.

Itihas-purana joint together is known as the fifth Veda.

Nepal is located in South Asia. The Indian subcontinent is also identified as the Bharatvarsha in the puranas. It is also known as Aryavarta. While performing Yajna, the Purohita/Brhamin recites Mahasankalpa. In case of Kathmandu, it is recited as:

'हरि ॐँ तत्सत् ॐँ विष्णु विष्णु विष्णु अद्य श्रीमद्भगवतो महापुरुषस्य विष्णोराज्ञा प्रवर्त्तमानस्य सकलजगत् सृष्टिकारिणो ब्रह्मणो द्वितीयपरार्द्धे श्रीश्वेतवाराहकल्पे सप्तमे वैवस्वत मन्वन्तरे अष्टाविंशतितमे कलियुगे कलियुगस्य प्रथमचरणे भारतवर्षे भरतखण्डे जम्बूद्रीपे आर्यावर्तान्तर्गत श्रीकृष्णगण्डक्या पूर्वभागे वाग्मत्यासमीपे पाशुपतक्षेत्रे विक्रमशके बौद्धावतारे आदि आदि.'।

'Hari om tatsat om Vishnu vishnu adya shrimadbhagavato mahapurushasya vishnorajnaya pravartamanasya sakala jagat srishtikarino brahmano dwitiyaparardhe shriswetavarahakalpe vaivaswatamanwantareashtavimshatitamekaliyuge kaliyugasyaprathamacharane bharatavarshe bharatakhnde jambudwipe cryavartantargata shrikrishnagandakya purvabhage vagmatyasamipe pashupatakshetre vikramashake bauddhavatare adi adi,'

In this Mahasankalpa, the terms bharatavarsha, Bharatakhanda, Jambudwipa, Aryavarta, Srikrishna Gandaki, Bagmati and Pashupatakshetra are used. All these are the geographical terms. The geography of today is different from that of Puranas. However, some of the elements are similar even today. The geologic history is an evidence to prove that the Antarctica was once a place of coal mines and Rajsthan was a region of glacier. This is an example of dramatic change in geography.

\section{CONCLUSION}

The paper was prepared with an objective to throw light on selected aspects of Vedas and Puranas with specific reference to brief introduction and geographical elements in them. The three types of Puranas are explained but the Bhagavatamahapurana was given central focus for this purpose. The paper has mentioned some of the rivers and mountains included in the Puranas. Their names are similar even today. It has also been stated that no one can find out the exact knowledge about the universe which is well identified as Vedic Cosmology. It has no limited boundary. It is endless. All the living beings are created by the God and at last merge into the God. The atheists do not believe the God. However, they accept the nature as all in all. All the living beings are created by the nature and their end also takes place in the icy hand of nature or Prakriti.

\section{REFERENCES}

Dikshit, P., 2004. Puranome kya Hai? Delhi: Pustak Mahal.

Jnawali, D., 2005. Aryasamajka Nidhika rupma Puranharu, Prajnachakshu Visheshanka, PP 62-64.

Jnawali, D. 2010, Ecology in Hinduism and Buddhism: Perspective on Religious Geography, in Pradhan, Pushkar K; Subedi, Bhim P and Khanal,Narendra R (ed), Environment, Livelihood and Micro enterprises. Kathmandu: Central Department of Geography.

Poddar, H. P., (ed.) 1997. Maharshi Vedavyasapraneeta Shrimadbhagavata Mahapuranam Part I, Gorakhpur: Govinda Bhavan Karyalaya.

Poddar,H.P.(ed.)1997.MaharshiVedavyasapraneeta Shrimadbhagavata Mahapuranam Part II, Gorakhpur: Govinda Bhavan Karyalaya.

Pandeya, R. 2002, Rigveda, New Delhi: Diamond Pocket Books Pvt. Ltd.

Tiwari, S. (nd), Origin of Environmental Science from Vedas, pdf file accessed on March 1 2014. 